\title{
Assessment of spermicides by a stripping technique against human spermatozoa
}

\author{
Janet Brotherton \\ Department of Gynaecological Endocrinology, Sterility and Family Planning, \\ Klinikum Steglitz of the Free University Berlin, \\ Hindenburgdamm 30, 1000 Berlin 45, Germany
}

\begin{abstract}
Summary. Fifty-two (52) compounds were tested for spermicidal activity by titration against human spermatozoa. The gradual decrease in mean sperm size was measured against increasing concentration of spermicide and the end-point was taken as the point at which all the peripheral cytoplasm had been removed and only the sperm core of nucleus and tail fibres remained. There were 14 compounds that produced this total effect. All were detergents, of various types, and the effect was purely physical. The most potent compounds caused complete stripping at $0.5-50 \mathrm{pmol} / \mathrm{cell}$ and most are already used in spermicidal preparations. A further 11 compounds, including sodium hypochlorite and some phenols, caused partial stripping, while 4 compounds caused sperm swelling. The test was not suitable for assessment of metabolic cell poisons.
\end{abstract}

\section{Introduction}

The methods of assessment and the types of potent spermicides have been reviewed by Bernstein (1974). The usual method of measuring the cytotoxic potencies of compounds against specific cell types is to measure the degree of inhibition of growth, i.e. of cell division. This method cannot be used to assess the potency of spermicides and it has been usual to measure some morphological or biochemical sperm characteristic as the end-point, e.g. the decrease in percentage of motile spermatozoa after a set time or the time taken for all the spermatozoa to become immotile. Since the work of Baker (1931) many possible spermicidal agents, as pure compounds (Holzaepfel, Greenlee, Wyant \& Ellis, 1959; Harvey \& Stuckey, 1962a,b) and as pharmaceutical preparations (Gamble, 1953, 1957; Hartman, 1959; Goldenberg \& White, 1975), have been tested in this way. Tests depending on the estimation of the inhibition of metabolic features, e.g. respiration, are relatively few.

A new method has now been developed based on the measurement of sperm size. During measurements of the size of human spermatozoa (Brotherton \& Barnard, 1974), it was found that human semen contains so many small fragments and droplets that it was first necessary to dissolve these by treating with Zaponin reagent (Coulter Electronics Ltd, Dunstable, England). This procedure also removed the peripheral cytoplasm from the spermatozoon, leaving the nucleus and the tail fibres to form the 'sperm core', which was the body measured. When it became possible to clean untreated spermatozoa, the loss of total sperm volume due to Zaponin treatment was found to be about $50 \%$ (Brotherton, 1975). Application of the technique to the spermatozoa of other species gave a wide range of values. Attempts were then made to separate sperm heads from tails, to measure their respective sizes and study their differing compositions. Although the heads and tails of rodent and rabbit spermatozoa were easily separated from each other, it was found that all procedures led to a significant loss in total sperm volume and that the methods were all unsuccessful for human spermatozoa (Brotherton, 1977a). Ultrasonication caused unspecific sperm fragmentation, rather than cleavage, and a large loss in total sperm volume. This work to find an agent that would cleave human spermatozoa has now been extended and several substances were found to strip spermatozoa in the same manner as Zaponin reagent. It has therefore been possible to assess their potency as spermicides by following the decrease in sperm size as the spermicide concentration is increased. 


\section{Materials and Methods}

A Coulter Counter, Model $Z_{B}$ Industrial, was used to count and size human spermatozoa as described previously (Brotherton \& Barnard, 1974). Human semen samples were obtained from the subfertility clinic and were selected for a count of greater than $40 \times 10^{6} / \mathrm{ml}$, normal motility and more than $60 \%$ normal cells. After suitable dilution in Isoton reagent (Coulter Electronics Ltd) the sperm count and size were determined before and after Zaponin treatment. Because of the normal debris in semen the size of the spermatozoa before Zaponin treatment could only be determined approximately. A sample of semen was then diluted with the same amount of Isoton and a known volume of the test substance in Isoton was added. Sperm count and size were measured after exactly $1 \mathrm{~min}$. A fresh portion of semen was taken for each point on the titration curve of a particular substance as it had previously been found that human spermatozoa in Isoton swell over a period of 1-2 h. Similarly, increasing concentrations of test substance could not be added to the same diluted semen sample as in a normal chemical titration as this invalidated the method of calculation. The amount of test substance was related to the number of spermatozoa present in each titration. All titrations were carried out at $\mathrm{pH} \mathrm{7.0-7.2}$ because preliminary investigations showed that sodium hydroxide alone would strip spermatozoa while hydrochloric acid caused swelling. An alkaline $\mathrm{pH}$ was found to be extremely detrimental to human spermatozoa.

All chemicals were purchased from Merck, Darmstadt, Germany, unless otherwise stated. The remaining chemicals were purchased from the German agents for the major international chemical firms indicated. Items identified by a trade name were from firms which were not necessarily the primary manufacturers.

\section{Results}

Text-figure 1 shows the titration curves obtained for some of the most potent spermicides. The lower horizontal line on each curve is the size of the sperm core after Zaponin treatment for that particular semen sample. It is equivalent to the 'all' effect in a microbiological assay (Brotherton, 1976a). The upper horizontal line is the approximate size of the spermatozoa before Zaponin treatment. It is

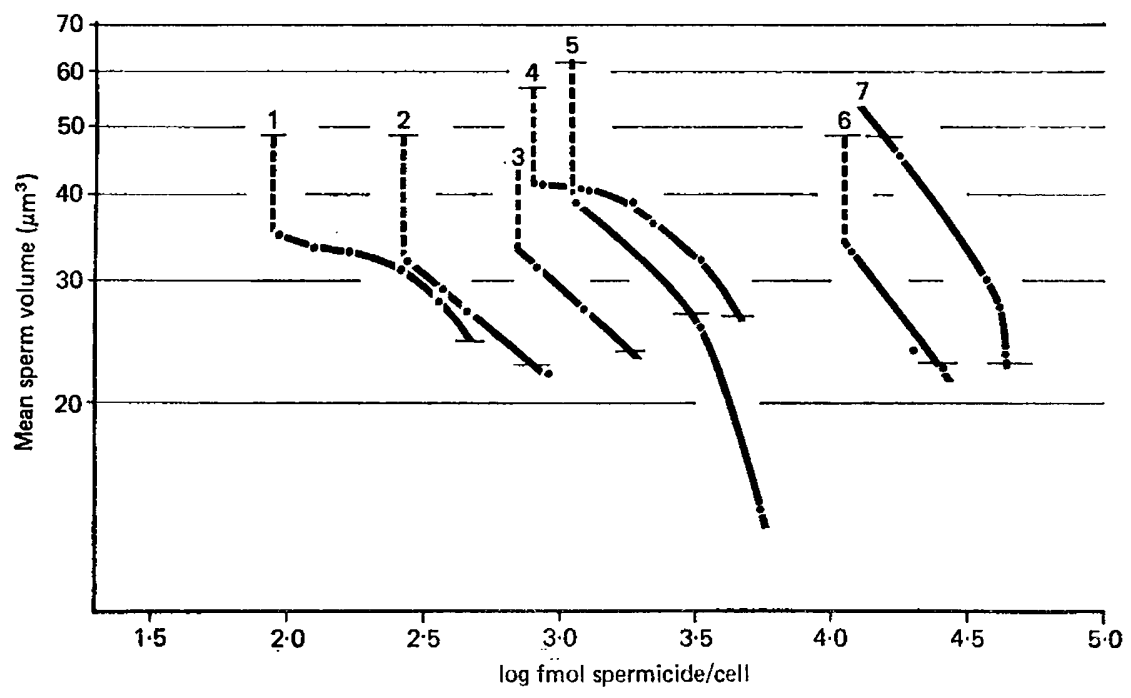

Text-fig. 1. Dose-response curves for the assay of spermicides by the stripping of human spermatozoa; see text for details. 1, Cetylpyridinium chloride; 2 , CTAB; 3, Hyamine $10 \mathrm{X} ; 4$, benzalkonium chloride; 5 , sodium lauryl sulphate; 6 , Triton $\mathrm{N}-101 ; 7$, Triton X-100. 
equivalent to the 'nothing' effect in a microbiological assay. In contrast to microbiological assays the whole length of the dose-response curve could not be determined because of the debris in untreated semen. The debris was only dissolved when the active substance had removed enough sperm cytoplasm to allow the sperm volume to approach that of the core and the size of the treated spermatozoa could then be measured accurately. Similarly the $\mathrm{ED}_{50}$ value could not be determined as in a microbiological assay. The end-point of the assay was taken as the amount of substance required to just strip the spermatozoa to the core size. This could be measured very accurately from the doseresponse curves and the values for the most potent spermicides are shown in Table 1.

Table 1. Minimum concentrations of reagents to produce $100 \%$ stripping of human spermatozoa

\begin{tabular}{lc}
\hline & $\begin{array}{c}\text { Conc. } \\
\text { (pmol/cell) }\end{array}$ \\
\hline Triisopropylnaphthalene sulphonic acid sodium salt (Serva) & $77 \cdot 6$ \\
Triton X-100 (Merck) & $43 \cdot 7$ \\
$N$-Dodecylpyridinium chloride (Merck) & $31 \cdot 6$ \\
Sodium deoxycholate (Merck) & 26.9 \\
Triton N-101 (Sigma) & 24.0 \\
$N$-Lauroylsarcosine sodium salt (Sigma) & 12.6 \\
Benzethonium chloride (Serva) & 6.03 \\
Benzalkonium chloride (Merck) & 4.57 \\
Teepol 710 (Serva) & 3.09 \\
Sodium lauryl sulphate (Merck) & 3.02 \\
Hyamine 10X (Sigma) & 1.82 \\
Saponin (Merck; B.D.H.) & 0.955 \\
CTAB (Merck) & 0.794 \\
Cetylpyridinium chloride (Merck) & 0.468 \\
\hline
\end{tabular}

Table 2. Approximate spermicidal potency of compounds that strip human spermatozoa incompletely

\begin{tabular}{lcc}
\hline & $\begin{array}{c}\text { Stripping } \\
\%\end{array}$ & $\begin{array}{c}\text { Conc. } \\
\text { (pmol/cell) }\end{array}$ \\
\hline Sodium hypochlorite & $37 \cdot 8$ & 489,000 \\
& $58 \cdot 3$ & 406,000 \\
& $43 \cdot 3$ & 923,000 \\
& $6 \cdot 0$ & 92,700 \\
Chloramine T (Merck) & $15 \cdot 5$ & 185,000 \\
& $55 \cdot 2$ & 277,000 \\
Brij 35 (Serva) & $18 \cdot 7$ & 9330 \\
\hline Sodium hydroxide & $9 \cdot 2$ & 2630 \\
& $14 \cdot 0$ & 10,900 \\
Benzyltrimethylammonium chloride (Merck) & $16 \cdot 5$ & 4580 \\
Ethyl potassium xanthate (Merck) & $35 \cdot 6$ & 16,300 \\
2-Naphthol (Merck) & $18 \cdot 4$ & $60 \cdot 3$ \\
& $45 \cdot 7$ & 151 \\
Sodium cholate (Merck) & $51 \cdot 5$ & 302 \\
4-n-Hexylresorcinol (Merck) & $17 \cdot 0$ & $97 \cdot 1$ \\
2,4,6-Trichlorophenol (Merck) & $18 \cdot 7$ & 155 \\
6-Chlorothymol (Merck) & $38 \cdot 3$ & $85 \cdot 6$ \\
& $37 \cdot 7$ & $61 \cdot 4$ \\
& $31 \cdot 1$ & 113 \\
& $48 \cdot 5$ & $24 \cdot 0$ \\
& $31 \cdot 4$ & $19 \cdot 1$ \\
& $77 \cdot 0$ & $11 \cdot 0$ \\
& $33 \cdot 1$ & $6 \cdot 34$ \\
& $37 \cdot 9$ & $4 \cdot 98$ \\
\hline & & \\
& &
\end{tabular}


Several substances were found that partly stripped human spermatozoa (Table 2). The addition of more substance either failed to bring about further stripping or was not possible for solubility reasons. As the core size was not reached it was not possible to compare their potencies with those of the compounds shown in Table 1 but an approximate idea can be obtained from the degree of stripping obtained relative to the approximate original size of the spermatozoa. Many of these substances appear to be almost as potent as spermicides as those shown in Table 1.

Table 3. Compounds (from Merck) which cause swelling of human spermatozoa

\begin{tabular}{lcc}
\hline & $\begin{array}{c}\text { Approx. } \\
\text { increase in } \\
\text { sperm vol. } \\
(\%)\end{array}$ & $\begin{array}{c}\text { Conc. } \\
\text { (pmol/cell) }\end{array}$ \\
\hline Hydrochloric acid & $18 \cdot 2$ & 1700 \\
Acetic acid & $7 \cdot 1$ & 439 \\
Sodium diethyldithiocarbamate & $3 \cdot 1$ & 4940 \\
Methylhydroquinone (toluhydroquinone) & $9 \cdot 7$ & $97 \cdot 4$ \\
\end{tabular}

Sperm swelling was observed with a few compounds (Table 3) and was also seen with some compounds that at higher concentrations completely stripped the spermatozoa. These cases probably represent interpolation of molecules into the cell membrane before enough becomes present to cause rupture. At this stage the action of the spermicide would be reversible as washing would remove the interpolated molecules. A number of likely spermicides or cell rupturing agents were found to be without effect on sperm size, although some prevented the subsequent stripping by Zaponin reagent (Table 4).

Table 4. Compounds which have no effect on sperm size

\begin{tabular}{|c|c|}
\hline No effect & $\begin{array}{l}\text { Protection against } \\
\text { subsequent } \\
\text { stripping with } \\
\text { Zaponin }\end{array}$ \\
\hline $\begin{array}{l}\text { Triton X-114 (Roth, Stuttgart) } \\
\text { Tergitol NP-40 (Sigma) } \\
\text { Polyvinylalcohol, Sigma Type II (Sigma) } \\
\text { Brij } 58 \text { (Serva) } \\
\text { Myrj } 59 \text { (Serva) } \\
\text { Glycerol (Merck) } \\
\text { Dioctylsulfosuccinic acid sodium salt (Serva) } \\
\text { n-Dodecylguanidine acetate (Merck) } \\
\text { 2,7-Dimethylbenzene sulphonic acid (Serva) } \\
\text { Nitrofurantoin + NaOH (Serva) } \\
\text { Nitrofurazone + NaOH (Serva) } \\
\text { Spermine tetrahydrochloride (Merck) } \\
\alpha \text {-Chlorohydrin (Merck) } \\
\text { Ricinoleic acid, Pract. (Eastman) } \\
\text { Dodecyltrimethylammonium chloride (Eastman) } \\
\text { Benzyldimethylammonium chloride (Eastman) } \\
\text { Trimethylammonium bromide (Eastman) } \\
\text { Nonyltrimethylammonium bromide (Eastman) }\end{array}$ & $\begin{array}{l}\text { Tween } 20 \text { (Serva) } \\
\text { Tween } 80 \text { (Serva) } \\
\text { Triton X-405 (Serva) } \\
\text { Pluronic F } 68 \text { (Serva) } \\
\text { Monflor } 71 \text { (Serva) }\end{array}$ \\
\hline
\end{tabular}




\section{Discussion}

The most potent spermicides belonged to several structural classes (Table 5). The strongest compounds were cationic detergents with a long carbon side chain, i.e. CTAB $>$ Hyamine 10X $>$ benzalkonium chloride $>$ benzethonium chloride. Compounds in which the cationic quaternary nitrogen was part of a 6-membered ring, e.g. cetylpyridinium chloride and $N$-dodecylpyridinium chloride were as potent. Slight variations in the length and structure of the carbon chain brought about large variations in the potency of the compounds: Hyamine 10X contains only an extra ring methyl group compared with benzethonium chloride but was about 3 times more potent, and cetylpyridinium chloride contains 3 more methylene groups in the carbon side chain than does $N$-dodecylpyridinium chloride but is about 68 times more potent. When the carbon chain was reduced to a single methyl group, as in benzyltrimethylammonium chloride, stripping potency was very much reduced and incomplete.

Table 5. Precise nomenclature and structure of the most potent spermicides

\begin{tabular}{|c|c|}
\hline Compound & Alternative name(s) with notes on stuctuure \\
\hline Benzalkonium chloride & $\begin{array}{l}\text { Alkylbenzyldimethylammonium chloride with the alkyls varying from } \mathrm{C}_{8} \mathrm{H}_{17} \text { to } \\
\mathrm{C}_{18} \mathrm{H}_{37} ; \text { Hyamine } 3700 \text { (Merck, Darmstadt: mol. wt approx. 365) }\end{array}$ \\
\hline Benzethonium chloride & $\begin{array}{l}\text { Benzyldiisobutylphenoxyethoxydimethylammonium chloride; } \\
\text { diisobutylphenoxyethoxyethyldimethylbenzylammonium chloride; } \\
\text { benzyldimethyl\{2-[2-( } p-1,1,3,3 \text {-tetramethylbutylphenoxy)ethoxy]ethyl }\}- \\
\text { ammonium chloride; Phemerol; Hyamine } 1622\end{array}$ \\
\hline Cetylpyridinium chloride & $N$-Cetylpyridinium chloride monohydrate \\
\hline CTAB & $\begin{array}{l}\text { Cetyltrimethylammonium bromide; cetrimonium bromide; citrimide; } \\
N \text {-cetyl- } N, N, N \text {-trimethylammonium bromide; hexadecyltrimethylammonium } \\
\text { bromide }\end{array}$ \\
\hline Hyamine 10X & $\begin{array}{l}\text { Methylbenzethonium chloride; benzyldiisobutylcresoxyethoxydimethyl- } \\
\text { ammonium chloride }\end{array}$ \\
\hline$N$-Lauroylsarcosine sodium salt & Sodium lauroylsarcosinate; Sarcosyl; Gardol \\
\hline Sodium lauryl sulphate & Sodium dodecylsulphate; SDS; dodecyl hydrogen sulphate sodium salt \\
\hline Teepol 710 & $\begin{array}{l}40 \% \text { secondary-Alkyl sulphate sodium salt in water; Gardinol; Dupanol; } \\
\text { Lissapol; Potency was calculated as if it had the same molecular weight as } \\
\text { sodium lauryl sulphate }\end{array}$ \\
\hline Triton X-100 & $\begin{array}{l}\text { p-Isooctylphenoxypolyethoxyethanol; Antarox CA-630; } \\
\text { polyethyleneglycol-mono-p-(1,1,3,3-tetramethylbutyl)-phenyl ether; } \\
\text { octylphenol polyethyleneglycol ether, } n=9-10 ; \\
\text { polyethyleneglycol } p \text {-isooctylphenyl ether; } \\
p \text {-(1,1,3,3-tetramethylbutyl)phenoxypolyethyleneglycol; } \\
o \text {-[4,(1,1,3,3-tetramethylbutyl)phenyl]deca(oxyethylene); } \\
\text { diisobutylphenoxypolyethoxyethanol (= name used by Ortho Pharmaceuticals } \\
\text { in U.K.) }\end{array}$ \\
\hline Triton N-101 & $\begin{array}{l}p \text {-Nonylphenoxypolyethoxyethanol; Nonoxynol 9; polyoxyethylated nonyl- } \\
\text { phenol; nonylphenolpolyethyleneglycol ether; polyethyleneglycol p-nonyl- } \\
\text { phenol ether }\end{array}$ \\
\hline Saponin (Merck, Darmstadt) & $\begin{array}{l}\text { An extract from the 'white soap wort', Gypsophila sp. (Caryophyllaceae), } \\
\text { containing gypsogenin ( } 3 \beta \text {-hydroxy-23-oxoolean-12-en-28-oic acid), a } \\
\text { triterpenoid, as the sapogenin, attached to a chain of sugars at the } \\
3 \beta \text {-hydroxy group, consisting mainly of glucose with small amounts of } \\
\text { arabinose, rhamnose and galactose. Potency was calculated by assuming that } \\
\text { the sugar chain consisted of } 9 \text { molecules of glucose, thus giving a mol. wt of } \\
2092 \text {. Note that this is not the same saponin defined under that generic name } \\
\text { in the Merck Index (Merck, Sharpe \& Dohme, U.S.A.) }\end{array}$ \\
\hline
\end{tabular}

Structural formulae may be obtained from the Merck Index. Only the most common trade names have been listed and many more are given in the Merck Index and are in use in various parts of the world. Commercially available vaginal contraceptive preparations usually contain one or more of these compounds under a proprietary trade name. 
Anionic detergents, such as sodium lauryl sulphate, Teepol $710, N$-lauroylsarcosine sodium salt and triisopropylnaphthalene sulphonic acid sodium salt, also showed great variations in potency with structure.

The greatest variations were shown by the neutral Triton detergents and the neutral bile salts. The side chain of Triton X-100 is the same as that of benzethonium chloride but it was about 7 times more potent, indicating the contribution of the polyethoxyethylene group. The length of this polyethoxyethylene group was important: for the iso-octylphenol compounds, $n=9-10$ for Triton $\mathrm{X}-100$, while $\mathrm{n}=7-8$ for Triton X-114 which had no effect on sperm size, and $\mathrm{n}=40$ for Triton X-405 which not only had no effect on sperm size but also prevented the subsequent stripping by Zaponin reagent. For the nonylphenol compounds, $n=9$ for Triton N-101, while $n=40$ for Tergitol NP-40 which had no effect on sperm size and was incompatible with Zaponin, producing a white precipitate. When the lengths of the molecules were the same, Triton $\mathrm{N}-101$ was about twice as potent as Triton $\mathrm{X}-100$.

In the bile salts, sodium deoxycholate was a potent spermicide but the reaction with the very closely related sodium cholate was very much reduced and did not proceed to complete stripping. Saponin (Merck, Darmstadt; also obtainable from B.D.H.) containing gypsogenin as the sapogenin was confirmed as one of the most potent cell lysing agents. Saponin (Roth, Stuttgart) was about 5 times less potent and did not induce complete stripping. The sapogenin is believed to be quillaic acid which has only one additional hydroxyl group on the triterpenoid molecule when compared with gypsogenin, while the carbohydrate side chain contains significant quantities of glucuronic and galacturonic acids rather than neutral sugars. Both preparations behaved differently from Zaponin reagent, in which the nature of the sapogenin has not been disclosed and which also contains acetic acid. Zaponin reagent produced full stripping in only $1 \mathrm{~min}$, whereas it was necessary to wait for $5 \mathrm{~min}$ for the other saponin preparations, the only substances for which such a wait was necessary before measuring the degree of stripping. All the other compounds acted virtually instantaneously. The spermicidal action of other triterpenoid saponin preparations has also been demonstrated (Stolzenberg \& Parkhurst, 1974; Setty, Kamboj, Garg \& Khanna, 1976).

The steroidal and triterpenoid structures are in the form of plates that can easily intercalate between similar molecules in cell membranes. The structures of the other spermicidal detergents suggest a similar mode of action, which is purely physical in nature, whereby the cell membranes continue to incorporate more substance until they lose their structure. Sperm stripping with these agents was often a continuous process and after the removal of the peripheral cytoplasm, the sperm core may be gradually digested until the spermatozoa are completely dissolved. This process occurred quickly with sodium lauryl sulphate.

Detergents have been widely applied to the dissolution of cell membranes, both for the outer cell membrane and for the membranes around the various subcellular components (Helenius \& Simons, 1975). Almost all the surfactants that are effective in solubilizing cell membranes have values for the hydrophilic:lipophilic balance (HLB) of $12.5-14.5$; e.g. 13.5 for Triton X-100 and 13.4 for Triton $\mathrm{N}-101$. Compounds with higher HLB values have also been used because they release mainly peripheral protein from membranes but do not dissociate the lamellar structure of the membrane. In the present study Brij $58($ HLB $=15 \cdot 8)$, Tween $20($ HLB $=16 \cdot 7)$, Tween $80($ HLB $=15 \cdot 0)$ and Triton $\mathrm{X}-405$ (HLB > 17) were ineffective as sperm stripping agents.

The spermicidal activities of some of the detergents tested have been previously measured as the lowest concentration needed to immobilize human spermatozoa after 30 min when a solution was mixed with an equal volume of semen $(0.3 \mathrm{ml})$ (Harvey \& Stuckey, 1962a). Spermicidal concentrations were $0.25-0.125 \%$ for sodium lauryl sulphate, $0.03-0.025 \%$ for benzalkonium chloride, $0.1-0.05 \%$ for CTAB, $0.05-0.025 \%$ for sodium dioctylsulphosuccinate; $0.5 \%$ Tween 80 was non-lethal. It was not possible to confirm in this study the high activity of sodium dioctylsulphosuccinate: at maximum solubility in Isoton there was no significant effect on sperm size. This compound is, however, known to be a potent spermicide and it is possible that it acts thus by a different mechanism. Of the 581 compounds screened by Holzaepfel et al. (1959) there were 31 surfactants among the 56 most potent compounds. However, nomenclature is too imprecise to permit identification, although benzethonium chloride, benzalkonium chloride and Hyamine 10X were certainly present, probably with 
Triton X-100 and Triton N-101. Of the non-detergents recognizable, I could obtain only 2-naphthol, 4-n-hexylresorcinol, ethyl potassium xanthate, sodium diethyldithiocarbamate and 2-methylhydroquinone. The first three were confirmed as potent spermicides although they did not strip to the core. Like 2,4,6-trichlorophenol and 6-chlorothymol these compounds are known to be potent bactericides and to digest bacterial membranes (Albert, 1973). Sodium diethyldithiocarbamate and 2-methylhydroquinone caused sperm swelling : the former was the most potent compound tested by Holzaepfel et al. (1959) and the dialkyldithiocarbamates in general are known to cause gross morphological changes in human spermatozoa (Rice, 1964).

Some spermicidal detergents have been used for the extraction of human and animal spermatozoa before biochemical investigation of specific components (Gall, Millette \& Edelman, 1974; Zaneveld, Wagner, Schlumberger \& Schumacher, 1974; Bedford, Bent \& Calvin, 1973; Hernandez-Montes, Iglesias \& Mujica, 1973) and this is currently an important area of sperm research.

Providing the formulation of the product ensures adequate availability of the active ingredient(s) to the spermatozoa, commercially available spermicides must be extremely effective. The safety of many of the compounds has also been demonstrated toxicologically (Smyth \& Calandra, 1969). Triton N-101 is the sole active ingredient in several spermicidal creams, jellies and pessaries, e.g. Patentex Oval (Patentex, Germany), Delfen Cream, Delfen Foam (Ortho Pharmaceuticals, Cilag Chemie) and Duracreme (London Rubber Industries), while Triton X-100 occurs in Ortho-Gynol, Preceptin Gel, Efpa Gel (Ortho). Sodium lauryl sulphate is found with boric acid in Ortho-Creme. Many other commercial preparations contain two or more potent spermicidal detergents, e.g. benzethonium chloride is found with Triton N-101 in Orthoform Pessaries (Ortho) and Emko (Gerhardt, Germany). Many of the preparations are formulated at about $\mathrm{pH} 4.5$ to accord with that of most of the vagina; an acid $\mathrm{pH}$ is itself detrimental to human spermatozoa but it is not necessary for the activity of the spermicides. Clinical trials have confirmed the effectiveness of the spermicidal detergent preparations. Tests with Patentex Oval foaming suppositories have shown a Pearl Index of $0 \cdot 8$ pregnancies per 100 women years for 63,759 cycles in 10,017 women (Rammstedt, 1974; Brehm \& Haase, 1975). (For definition and discussion of the Pearl Index see Brotherton, 1976b.) Post-coital tests showed that only non-motile spermatozoa were present in the vagina and none was in the cervical canal. Delfen Cream and Preceptin Gel had a Pearl Index of 9.1 in a 6-year study in 980 women (Rovinsky, 1964). A vaginal foam containing $8 \%$ Triton $\mathrm{N}-101$ and $0 \cdot 2 \%$ benzethonium chloride had a Pearl Index of 3.98 (Bernstein, 1970). A vaginal foam tablet containing at least four potent spermicides has been shown to be effective (Ishihama \& Inoue, 1972) and vaginal inserts containing benzalkonium chloride, Triton $\mathrm{N}-101$ and sodium lauryl sulphate inhibit sperm motility very quickly (Chiari \& Rappelli, 1975).

Ejaculated rabbit spermatozoa have been counted automatically after treatment with chloramine T (Kihlström, Carlsson \& Larsson, 1975). Rabbit semen contains even more debris than that of man and it was not possible to count and size the spermatozoa without prior Zaponin treatment (Brotherton, 1975). In the present study chloramine $\mathrm{T}$ dissolved some of the debris in human semen but a loss of $10-20 \%$ of the total sperm volume also occurred. Chloramine $T$ is therefore a weak spermicide with stripping properties. Sodjum hypochlorite has similar properties but is even weaker. Normal hygiene involving common soap (sodium lauryl sulphate) and swimming pool water (sodium hypochlorite) are sufficient to kill human spermatozoa.

Sperm size was not affected by $\alpha$-chlorohydrin although the compound has been shown to inhibit motility and reduce metabolic activity (Hommonnai, Paz, Sofer, Yedwab \& Kraicer, 1975; Mohri, Suter, Brown-Woodman, White \& Ridley, 1975). Similarly the nitrofurans had no effect on sperm size although they have been shown to inhibit sperm motility in vitro (Albert, Mininberg \& Davis, 1975; Albert, Salerno, Kapoor \& Davis, 1975). It is clear that the stripping test does not apply to metabolic cell poisons, such as quinine and emetine also, whose mode of action is by the inhibition of some central biochemical process after they have entered the intact cell.

Quinine and emetine are currently being investigated by WHO as spermicidal agents for incorporation into intracervical devices. It is therefore pertinent to consider the results from the stripping assay in relation to the potency of these agents in cytocidal assays. In terms of absolute potency, the spermicides shown in Table 1 are about 1000 times less potent as cytocides than the best compounds 
which act by inhibiting cell 'growth' or specific metabolic processes. The results from cytocidal assays against yeasts (Brotherton, 1976a) and trichomonads (Brotherton, 1977b) showed that quinine was not among the most effective compounds although emetine was very potent and that the non-specific and entirely physical mechanism of action of the stripping agents is a relatively weak method of killing cells compared with specific metabolic agents but is quicker.

\section{References}

Albert, A. (1973) Selective Toxicity, 5th. edn, pp. 468478. Chapman \& Hall, London.

Albert, P.S., Salerno, R.G., KaPOOR, S.N. \& Davis, J.E. (1975) The nitrofurans as sperm immobilising agents, their tissue toxicity and their clinical application in vasectomy. Fert. Steril. 26, 485-496.

Albert, P.S., MininberG, D.T. \& Davis, J.E. (1975) The nitrofurans as sperm immobilising agents: their tissue toxicity and their clinical application. $\mathrm{Br} . J$. Urol. 47, 459-462.

BAKER, J.R. (1931) The spermicidal powers of chemical contraceptives. J. Hygiene 31, 189-199.

Bedford, J.M., BeNT, M.J. \& CALvin, H. (1973) Variations in the structural character and stability of the nuclear chromatin in morphologically normal human spermatozoa. J. Reprod. Fert. 33, 19-29.

BERNSTEIN, G.S. (1970) Clinical effectiveness of an aerosol contraceptive foam. Contraception 3, 3743.

Bernstein, G.S. (1974) Physiological aspects of vaginal contraception. Contraception 9, 333-345.

BreHM, H. \& HAASE, W. (1975) Die Alternative zur hormonalen Kontrazeption. Med. Welt. 26, 1610 1617.

Brotherton, J. (1975) The counting and sizing of spermatozoa from ten animal species using a Coulter Counter. Andrologia 7, 169-185.

Brotherton, J. (1976a) Biological assay of fungicides against yeasts in vitro using a Coulter Counter. Mykosen 19, 361-372.

Brotherton, J. (1976b) Sex Hormone Pharmacology, pp. 211-212. Academic Press, London.

Brotherton, J. (1977a) The splitting of sperm heads from tails in eight mammalian species and the measurement of their sizes. Andrologia 9, 1-14.

Brotherton, J. (1977b) Biological assay of potential trichomonacides in vitro using a Coulter Counter. Arzneimittel-Forsch. (in press).

Brotherton, J. \& BARNARd, G. (1974) Estimation of number, mean size and size distribution of human spermatozoa using a Coulter Counter. J. Reprod. Fert. 40, 341-377.

ChIARI, G. \& RAppelli, F. (1975) In vitro spermicidal activity and therapeutic use of a benzalkonium chloride based product (Agena). Minerva Gin. 27, 895-899.

Gale, W.E., Millette, C.F. \& Edelman, G.M. (1974) Chemical dissection of mammalian spermatozoa. Acta endocr., Copenh. 78, Suppl. 194, 154-172.

Gamble, C.J. (1953) An improved test of spermicidal activity without dilution or mixing. J. Am. med. Ass. 152, 1037-1041.
Gamble, C.J. (1957) Spermicidal times as aids to the clinician's choice of contraceptive materials. Fert. Steril. 8, 174-184.

Goldenberg, R.L. \& White, R. (1975) The effect of vaginal lubricants on sperm motility in vitro. Fert. Steril. 26, 872-873.

Hartman, C.G. (1959) Annotated list of published reports on clinical trials with contraceptives. Fert. Steril. 10, 177-189.

HaRvey, C. \& Stuckey, R.E. (1962a) Spermicidal activity of surface active agents. J. Reprod. Fert. 3, 124-131.

HaRvey, C. \& Stuckey, R.E. (1962b) A new method of comparison of spermicidal activities. $J$. Reprod. Fert. 3, 132-137.

Helenius, A. \& Simons, A. (1975) Solubilisation of membranes by detergents. Biochim. biophys. Acta 415, 29-79.

Hernandez-Monres, H., Iglesias, G. \& Mujica, A. (1973) Selective solubilisation of mammalian spermatozoa structures. Expl Cell Res. 76, 437440.

Holzaepfel, J.H., Greenlee, R.W., Wyant, R.E. \& ElLIS, W.C. (1959) Screening of organic compounds for spermicidal activity. Fert. Steril. 10, 272-284.

Homonnai, Z.T., Paz, G., Sofer, A., Yedwab, G.A. \& KRAICER, P.F. (1975) A direct effect of $\alpha$-chlorohydrin on motility and metabolism of ejaculated human spermatozoa. Contraception 12, 579-588.

Ishihama, A. \& INoue, T. (1972) Clinical field trial of a new contraceptive vaginal foam tablet. Contraception 6, 401-410.

Kihlström, J.E., Carlsson, R. \& Larsson, M. (1975) A simple method for automatic counting of rabbit spermatozoa. $J$. Reprod. Fert. 43, 371-372.

Mohri, H., Suter, D.A.I., Brown-Woodman, P.D.C., White, I.G. \& RIDLEY, D.D. (1975) Identification of the biochemical lesion produced by $\alpha$-chlorohydrin in spermatozoa. Nature, Lond. 255, 75-77.

RAMMSTEDr, D. (1974)Klinische und in vivo Erfahrungen mit einem neuen lokal anwendbaren Antikonzipiens. Med. Welt. 25, 1127-1128.

RICE, E.W. (1964) Morphological changes in human spermatozoa following treatment of semen with certain dialkyldithiocarbamates. Expl Cell Res. 34, 186-188.

Rovinsky, J.J. (1964) Clinical effectiveness of a contraceptive cream. Obstet. Gynec., N.Y. 23, 125-131.

SetTy, B.S., KamboJ, V.P., Garg, H.S. \& Khanna, N.M. (1976) Spermicidal potential of saponins isolated from Indian medicinal palnts. Contraception 14, 571-578. 
SmYtth, H.F. \& Calandra, J.C. (1969) Toxicologic studies of alkylphenol polyoxyethylene surfactants. Toxic. appl. Pharmac. 14, 315-334.

Stolzenberg, S.J. \& PARKhuRst, R.M. (1974) Spermicidal actions of extracts and compounds from
Phytolucca dodecandra. Contraception 10, 135-143. ZAMEVELD, L.J.D., WAGNER, L., SCHLUMARERGGR, H.D.\& Schumacker, G.F.B. (1974) Immunological and biochemical studies on fractionated bull spormatozoa. J. Reprod. Fert. 38, 411-424.

Recetred 28 January 1977 